\title{
THE JUSTICIABILITY OF RELIGION
}

\author{
SATVINDER S. JUSS
}

Professor of Law, Dickson Poon School of Law, King's College, University of London; Barrister, Gray’s Inn

\begin{abstract}
In Shergill \& Others v. Khaira \& Others [2014] UKSC 33, the UK courts considered whether a Sikh holy saint had the power to dismiss trustees who questioned his "succession" to the religious institution of the Nirmal Kutia Johal. The Supreme Court, reversing the decision of the Court of Appeal that religious questions were "nonjusticiable," reinstated the judgment at first instance of the High Court to the contrary. The decision of the Supreme Court is important because whenever questions of the identification and legitimacy of successors to a religious institution have arisen, their "justiciability" before a secular court has invariably been a bone of contention on grounds that it threatens the autonomy of religious institutions. In Shergill the Supreme Court got around these concerns by drawing a normative distinction between the public law of the land (which the courts are required to determine), and the internal private law of a religious institution on matters of succession, ordination, and removal (which are not in themselves for the courts to decide). But Shergill also went further than previous case law in two respects. First, the fundamental tenets of a belief system are capable of an objective assessment by a secular court provided that there is public law element to a dispute, in which case the court can then decide on the fitness of the successor for office. This means there is no general presumption that a secular court is barred from considering religious questions per se. Second, these principles apply just as much to the judicial consideration of non-Christian faiths as they to the Christian religion, and this is so notwithstanding the court's unfamiliarity with other faiths.
\end{abstract}

KEYWORDS: Sikhs, Shergill, justiciability of religion

\section{INTRODUCTION}

In Shergill \& Others $v$ Khaira \& Others [20I4] UKSC 33, the UK Supreme Court settled the thorny question of religion and its justiciability in Church-State relations. This was important given the question: to what extent can religions change their doctrine and religious government and still be entitled to hold their property whilst professing those new doctrinal beliefs? The issue has been recently explored by Robert Meakin, ${ }^{\mathrm{I}}$ whose discussion of the leading cases ${ }^{2}$ has led him to the observation that, " $\left.\mathrm{t}\right] \mathrm{h}$ here is a tension between respecting donors' intentions where they give to a religion with doctrinal beliefs

I Meakin, "Property Rights for Dissenting Members of Religious Charities," Charity Law and Practice Review I 5 , no. 4 (20I2-I 3$): 55-68$, at 55 .

2 The cases discussed include General Assembly of the Free Church of Scotland v. Overtoun [1904] AC 5 I 5 (I 9047 F (HL) I); Varsani v. Jesani [I999] Ch 219; Craigdallie v. Aikman (I8I3) I Dow I, I4-I6; Attorney General v. Pearson (I8I7) 3 Mer 353, 400-OI, 36 ER I36, I 50; Deane v. Burne [2009] EWHC I250 (Ch); White \& Ors v. Williams \& Ors [2010] EWHC 940 (Ch); Rai and Others v. Charity Commission for England and Wales [20I2] EWHC IIII (Ch); Williamson v. Archbishop of Canterbury and Archbishop of York Church Commissioners [1996] EWCA Civ 600; HH Sant Baba Jeet Singh Ji Maharaj v. Eastern Media Group \& Anor 
which exists at that time and allowing religions to develop." 3 He refers to "a line of I 9 th century decisions of the court ... which made it clear that, unless the trust deed expressly provided for the amendment of doctrines (including religious government) or a schism, then church property would be held subject to the original doctrines contained in or referred to in the trust deed." 4 The courts over the years have had comparatively less opportunity, however, to concern themselves with challenges made to successors of religious institutions. Varsani v. Jesanis (discussed below) was one such case; however, it did not reach the House of Lords (the court of last appeal at the time ${ }^{6}$ ) being determined instead by the Court of Appeal. Thus, Shergill in the Supreme Court was the first case of its kind before that apex court, raising questions not just of belief, doctrine, and church government but also of the identification and legitimacy, in the sense of fitness for office, of successors to a religious office. 7

At the heart of the nineteenth century decisions was the Free Church Case. ${ }^{8}$ That case has since been strangely obscured, nor has it been free from difficulty in application. Thus, writing in 2002 , Frank Cranmer, noted that "the applicability of the judgment to any individual Church, whether Established or not, remains problematical, depending as it does on precisely what constitutes 'doctrine." " He concluded that "though it is almost a hundred years old, the Free Church Case $\left[{ }^{10}\right]$ still casts a long shadow." II Following the Supreme Court decision in Shergill, Russell Sandberg suggested that the principle of nonjusticiability is not based on a general principle that religious bodies or groups "enjoy a spiritual independence or freedom that places them above, or exempts them from, the law of the land," or that religion inhabits a "civil rights-free zone"; rather, it is based on the principle that the courts "will abstain from adjudicating on the truth, merits or sincerity of differences in religious doctrine or belief and on the correctness or accuracy of religious practice, custom or tradition." ${ }^{2} 2$ Julian Rivers has contrasted this with the "modern doctrine," which holds that courts should "not even resolve disputed questions of religious doctrine and government as matters of fact" and that such practices "lead[] to a curious instability in the law" between denial of a remedy to the

[20I0] EWHC I294 (QB); Free Church of Scotland (Continuing) v. General Assembly of the Free Church of Scotland [2005] CSOH 46.

3 Meakin, "Property Rights for Dissenting Members of Religious Charities," 56.

4 Ibid., 57 (referring to the case of Craigdallie v. Aikman (I8I3) I Dow I).

5 [1999] Ch 219.

6 In 2005 , Parliament passed the Constitutional Reform Act, placing the House of Lords appellate jurisdiction in a newly created Supreme Court. Constitutional Reform Act 2005 (c. 4).

7 In fact, the Shergill case originally arose out of a number of suits from a decade-long litigation that straddled defamation law. At its heart was the issue of the declaration of the head of a religious order, from a minority religious faith the doctrinal beliefs of which were not necessarily easy for the UK secular courts to fathom and pronounce upon. When in Baba Jeet v. Singh it was alleged that an article in the Sikh Times damaged the reputation of the Third Holy Saint by describing him as the leader of a "cult" who, as an imposter, had produced false trust deeds to sack the trustees of the High Wycombe gurdwara in northwest London, the action was stayed because it raised issues that were nonjusticiable. Similarly, when another libel claim arose in Shergill v. Purewal, [20Io] EWHC $3610(\mathrm{QB})$, from three articles written by a journalist who attacked the Third Holy Saint for having deviated from orthodox Sikh religious doctrine and misleading his supporters, that claim, too, was stayed by the court as not giving rise to justiciable issues. The Supreme Court in Shergill had to decide to what extent a policy of judicial abnegation was sustainable in a modern era of cultural diversity and religious pluralism.

8 Free Church of Scotland (Continuing) v. General Assembly of the Free Church of Scotland [2005] CSOH 46.

9 Cranmer, "Christian Doctrine and Judicial Review: The Free Church Case Revisited," Ecclesiastical Law Journal 6, no. 3I (2002): 3I 8-3I.

Io See, "The Westminster Confession of Faith," Center for Reformed Theology and Apologetics, http://www. reformed.org/documents/wcf_with_proofs/.

I I Cranmer, "Christian Doctrine and Judicial Review," 33 I.

I2 Russell Sandberg, "Khaira and Others v. Shergill and Others: Religious Doctrine-Non-Justiciability," Ecclesiastical Law Journal I5, no. I (2013): I2I-22. 
claimant on the one hand, or the search for a wholly nonreligious basis for legal decision making on the other. ${ }^{13}$ Peter Smith has argued that the decision in Shergill could "herald an avalanche of defamation claims in a range of familiar religions." " 4 He refers to how "[ $t]$ here has even been an attempt at a private prosecution on the basis of the 'untruth' of the Mormon faith." ${ }_{5}$ Although striking individual cases do come to mind in the field of religious rights adjudication, it is important as well to note the more guarded view expressed recently by the deputy president of the UK Supreme Court, Baroness Hale, to the effect that in most cases the courts are not at all concerned with the conformity of religious beliefs with religious laws but simply with protecting the freedom to hold and manifest those beliefs. ${ }^{16}$

Although it is certainly correct that adjudicating on matters arising from the law of the land must not be confused with adjudicating on matters of religious doctrine, I argue in this article that the Shergill decision in the Supreme Court goes further than any other before it in paving the way for the judicial adjudication of matters of faith because it collapses the distinction between doctrinal and nondoctrinal matters so as to track the justiciable and nonjusticiable boundaries between public law and private law. As I have elsewhere explained, the Shergill decision emphasizes "inclusivity" and "looks to the future." ${ }^{17}$

\section{THE STRUCTURE OF RELIGIOUS GOVERNANCE IN THE UNITED KINGDOM}

In the United Kingdom, if religions are structured they generally have a religious constitution. Having a constitution helps regulate religious life according to certain organizational rules. The

I3 Julian Rivers, The Law of Organized Religions: Between Establishment and Secularism (Oxford: Oxford University Press, 20I0), 73. See also Rivers's preference for the secular approach to Blake v. Associated Newspapers Ltd [2003] EWHC 1960: "One can easily distinguish between claims which are simply true or false (eg that a person does or does not hold a certain position in a certain religious organization) and claims which depend on a theological judgment." Ibid., I45.

I4 Peter Smith, "The Problem of the Non-Justiciability of Religious Defamations," Denning Law Journal, no. 27 (20I5): 24 I-57, at 257 .

I5 Smith refers to Thomas Phillips v. Thomas Monson [20I4] Westminster Magistrates Ct (District Judge Riddle):

It is obvious that this proposed prosecution attacks the doctrine and beliefs of the Mormon Church, and is aimed at those beliefs rather than any wrong-doing of Mr. Monson personally. The purpose is to use criminal proceedings to expose the false (it is said) facts on which the church is based. It is inevitable that the prosecution would never reach a jury, even if Mr. Monson chooses to attend. To convict, a jury would need to be sure that the religious teachings of the Mormon Church are untrue and misleading. That proposition is at the heart of the case. No judge in a secular court in England and Wales would allow that issue to be put to a jury. It is non-justiciable.

Ibid., $256 \mathrm{n} 84$

I6 Baroness Hale, "Secular Judges and Christian Law," Ecclesiastical Law Journal I7, no. 2 (2015): I70-8 I. These statements from Baroness Hale come in a review of Norman Doe's recent book, Christian Law: Contemporary Principles (Cambridge: Cambridge University Press, 2013), which compares and contrasts the internal regulations of churches and seeks to identify principles common to churches across the denominational spectrum. Baroness Hale reviews the religious questions that have come before the House of Lords and Supreme Court since 2004 and seeks to identify the principles governing the secular courts' approach to religious questions. She maintains that the relationship between those principles and the principles outlined in Christian law is far from clear, even while an understanding of the rules of particular religious bodies is sometimes necessary for secular judges deciding civil rights in a religious context.

I7 Satvinder S. Juss, "Back to the Future: Justiciability, Religion and the Figment of 'Judicial No-Man's Land," Public Law, no. 2 (April 2016): 198-206, at 199-200. 
structured religions will, concomitantly with their constitutions, routinely have a separate charitable trust or a charitable company (the latter may also be described as a "trust deed"). This enables the particular religious institution (which may also be referred to as "the religious constitution") to hold church property. This was the situation in the Shergill case.

It is not uncommon for a charitable trust or company alone to serve both functions. Where, however, there is a religious constitution, it may carry a power of amendment. Such power will enable amendment of a religious doctrine, provided that the trust deed refers to such doctrine in general terms. Once an amendment to religious doctrine or religious government occurs, this will then be incorporated into the trust deed by reference. The purpose is to allow, and not restrict, religious institutions in their growth and development, in the given context of the prevailing times. In this way religious institutions can retain the vestiges of a "living church" and not a dead ritual. The sentiment was expressed by Lord MacNaghten in the seminal I904 case of General Assembly of the Free Church of Scotland v. Lord Overtoun:

Was the Free Church by the very condition of her existence forced to cling to her subordinate standards with so desperate a grip that she has lost hold and touch of the supreme standard of her faith? Was she from birth incapable of growth and development? Was she (in a word) a dead branch and not a living Church? ${ }^{18}$

Despite the judicial recognition of the need to ensure that religious institutions could exist as "a living church" in English law, a line of nineteenth-century church cases established a tradition that it was the original doctrines of the religious institution, as enshrined in the trust deed (or what has also been described above as the charitable company), that would determine how church property would be held. That was, of course, unless there existed an express provision in the trust deed allowing for amendment of the doctrines, changes in the religious government of the institution, or a schism within the church institution.

The governing rule arose in the Edwardian era from the decision of the House of Lords in Free Church v. Lord Overtoun. ${ }^{19}$ This case arose out of a union between the Free Church of Scotland and the United Presbyterian Church in I900, resulting in the new United Free Church. As part of the union, the new trustees of the United Free Church had the former Free Church property passed on to them. A dispute arose regarding the new United Free Church's asserted power to amend the doctrines of the former Free Church's trust, as the doctrines of the Free Church of Scotland and the United Presbyterian Church differed.

The Free Church of Scotland was established in I 843 and claimed to be no different from the established Church of England, except that in spiritual matters they rejected state intervention under their doctrine and system. They did, however, adhere to two cardinal precepts. The believed, firstly, in the establishment principle, in recognizing a church supported by the state. They also believed, secondly, in the Westminster Confession of Faith ${ }^{20}$ as well as in the Calvinist doctrine of double predestination. ${ }^{2 \mathrm{I}}$

I 8 [1904] AC 5I5 (I904 7 F (HL) I).

I9 Ibid., 6I3.

20 The Westminster Confession of Faith provides for (I) the real presence in the sacrament, (2) the supreme authority of God's Word, and (3) the catholicity of the church. It specifically addresses the true preaching of the Word, the right administration of the sacraments, and discipline. "The Westminster Confession of Faith," last accessed July I3, 20I7, http://www.reformed.org/documents/wcf_with_proofs/.

2I Under Calvinist theology, where God exercises control over the world, the doctrine of "Predestination" refers to the belief that God appointed the eternal destiny of some to salvation by grace, while leaving the remainder to receive eternal damnation for all their sins, including their original sin. Calvinists believe that people are 
The United Presbyterian Church, ${ }^{22}$ with which the Free Church had now formed a union, was also a church that had disaffiliated itself from the established Church of England. However, the United Presbyterian Church accepted neither the Establishment principle nor, in its entirety, the Westminster Confession.

Not surprisingly in these circumstances, some members of the former Free Church objected to the United Presbyterian Church, maintaining that there existed no power to amalgamate with an institution that did not subscribe to the same doctrines, thereby requiring changes in the doctrine of the former Free Church. When the objecting members of the Free Church brought a legal claim for a breach of trust of the transferred trust property, the Earl of Halsbury LC gave a resounding declaration that a court of law "has nothing to do with the soundness or unsoundness of a particular doctrine ... a Court has simply to ascertain the original purpose of the trust." ${ }^{23}$ The kernel of the principle that a court of law must give effect to the original purposes of the trust, and not to any attempted variation of it, lay in the Earl of Halsbury's declaration that

I do not suppose that anyone will dispute the right of any man, or any collection of men to change their religious beliefs according to their consciences; but when men subscribe money for a particular object and leave it behind them for the promotion of that object, their successors have no right to change the object endowed. ${ }^{24}$

The Earl of Halsbury LC not only skillfully avoided having to enter the fray of religious disputation but proceeded to determine the dispute at hand as one which was purely civil. As he observed, the "so-called union" 25 was in truth not a synthesis of religious belief, but was effectively a coalition undertaken for administrative purposes. The result was that, where a difference in doctrine arose each of the united churches would adhere to their separate religious beliefs. In this way, it was possible for the majority of the House of Lords to conclude that the doctrinal positions of the former Free Church remained the same after the union in 1900 as they were before the union. The doctrine of the Free Church was embedded in the trusts relating to its property. This being so, the property was held for the Free Church now, just as it was then. No power existed in the church documents for the Free Church to deviate, diverge, or depart from the doctrine of its church because in the church documents there existed no express authority providing for severance or estrangement. ${ }^{26}$ There was no power to "subvert or destroy fundamental and essential principles of the Church." ${ }^{27}$ In this way the principle was established that when it comes to the resolution of property disputes the original religious doctrine must apply to the trusts which relate

predestined and effectually called in due time to faith by God. "Double predestination" in Calvinism is the view that God has actively chosen some people for damnation, as well as others for salvation. For an early influential discussion of this doctrine, see Edward A. Dowey, Jr., The Knowledge of God in Calvin's Theology (New York: Columbia University Press, I965).

22 The United Presbyterian Church of Scotland (I 847-I900) was formed in I847 by the union of the United Secession Church and the Relief Church, and it was a Scottish Presbyterian denomination. In 1900 it merged with the Free Church of Scotland. It then formed the United Free Church of Scotland. In I 929 it merged again with the Church of Scotland. In this way, for most of its existence the United Presbyterian Church was the third largest Presbyterian Church in Scotland. Like Scots Presbyterianism, it espoused a liberal tradition. Free Church v. Lord Overtoun [1904] AC 5I 5 (I904 7 F (HL) I), 6I3

24 Ibid., 623.

25 Ibid., 627

26 Ibid., 6I3-I4.

27 Ibid., 719. 
to the specified property, unless it can be shown that there exists in the religious charities an express power to revise, alter, or change, their creed or provide for alienation of doctrine.

In I999, however, there arose the case of Varsani $v$. Jesani, ${ }^{28}$ in which, under pressure from the challenges posed by new, emerging faiths in the pluralistic and diverse society of Britain, the Court of Appeal considered how property disputes between religious cabals could be determined where the religious constitution does not make any provision for doctrinal developments. The case involved a Hindu sect that had divided into two camps. The authority and divine status of the successor to the founder of the sect was recognized by the majority camp, but the minority camp challenged his legitimacy as the rightful successor to the original founder on account of allegations of misconduct levied against him. The rupture between the two camps was so antagonistic that neither could worship together in the same temple. The question was whether (and if so, to what extent) the nineteenth-century cases now applied to a case such as this. If the nineteenth-century cases controlled, those in the minority camp could have the court make an order in their favor only if they adhered to the original doctrinal beliefs of the Hindu sect, and their use of the property would be so restricted, ${ }^{29}$ as this was the only way that the original trusts of the property could be carried out.

The court, however, took a radical approach to the problem before it and held that although the purpose of the religious institution here was, in accordance with the precepts and canons of Muktajivandasji, to advocate, endorse, and support the faith of Swaminaryan, the way in which that purpose was to be achieved could not be divorced from the recognition of the fact that there had occurred a factional split in the sect. This had resulted in the original purpose's now being unattainable because neither of the two camps felt able to use the trust property in worship together. The decision in Varsani v. Jesani was, nevertheless, a decision of the Court of Appeal, whereas the long-standing and highly venerated judgment in Free Church v. Lord Overtoun stood as a decision of the House of Lords. The law therefore stood in some confusion. Was it time to discard the "traditional" approach in the Free Church case in favor of the "modern" approach in Varsani? Or was Varsani a heresy that, when the Supreme Court (previously House of Lords) finally had the opportunity, it should discard with relish, as outmoded and outdated jurisprudence, ill-suited to the demands of modern society? In Shergill, after a long series of intractable disputes in the lower courts, the Supreme Court finally answered that question.

\section{THE SHERGILL CASE}

In the I980s some members of the Sikh community in England decided to establish three separate Sikh temples, or gurdwaras, under the guardianship of His Holiness Sant Maharaj Baba Gian Singh Ji, "the First Holy Saint" of the sect of Nirmal Kutia Johal. ${ }^{\circ}$ His Holiness was the religious head of the abode of saints who belonged to the order of Nirmal Kutia. The issue in the Shergill case was whether, with the death of the First Holy Saint in 200I, and the early death of the Second Holy Saint, who had succeeded him in 2003, the Third Holy Saint, Sant Jeet Singh Ji Maharaj, could remove trustees of two gurdwaras, who had put their signatures on a revised 2003 constitution. The gurdwaras had been installed across the length of England, in Bradford, Birmingham, and High Wycombe. The eight trustees now claimed that their agreement was conditional on the

28 [1999] Ch 219.

29 Ibid., 232.

30 Nirmal means "pure." Kutia refers to the House of Reeds that he built. Johal is the village where he settled in north India. 
production of a valid will of the Second Holy Saint appointing the Third Holy Saint as his successor, failing which they would not recognize the Third Holy Saint. At the core of the dispute was a I99I deed that gave power (at the time of the incumbency of the First Holy Saint) to remove and appoint trustees to "the Saint or his successors" (as the deed stipulated). The recalcitrant trustees maintained that only the First Holy Saint as "the Saint" at the time, had the power to remove and appoint trustees, and in any event the Third Holy Saint was not a legitimately appointed "successor" in title. The Third Holy Saint accordingly brought proceedings in court to remove the recalcitrant trustees, who then sought to strike out the claim on grounds that the proceedings were nonjusticiable as they involved the appointment of a successor according to the religious doctrine and practice of the Nirmal Kutia Johal. ${ }^{31}$

The High Court judge at first instance held this was no reason not to hear the claim. The issue rested on the construction of the trust deeds and required "not an establishment of the propriety or the validity of a process by which the [Third Holy Saint] may have succeeded to come to be regarded as holding office of Holy Saint but whether, as a matter of fact, he has become sufficiently recognized as a the holder of that office to be considered to be a person described as having a particular power in the English deed, the construction of which is before the court." ${ }^{22}$ The judge dismissed the application to strike out the claim as nonjusticiable.

On appeal, the Court of Appeal, in a single judgement given by Mummery LJ (which Hooper and Pitchford LJJ joined) disagreed with the judge at first instance, holding that the issue turned on religious beliefs of the sect of the Nirmal Kutia Johal, which were not justiciable by the English courts. The matter then went to the Supreme Court to determine whether the Third Holy Saint, Sant Jeet Singh Ji Maharaj, could remove trustees as a "successor" to the First Holy Saint under the I99I deed. The Supreme Court disagreed with the Court of Appeal, holding that the case was justiciable and that it could decide issues of doctrine and practice where this was necessary to determine private rights and interests created by public law. It is in this way that the distinction between justiciable and non-justiciable boundaries between the realms of public and private law were collapsed by the Supreme Court.

\section{THE JUSTICIABILITY OF RELIGION IN THE UNITED KINGDOM}

The judicial canon of "nonjusticiability" is split into two distinct areas in the United Kingdom. The first has roots in English constitutional law. The doctrine has constitutional significance in two separate respects. First, under the doctrine of the Separation of Powers, an issue is treated beyond the constitutional competence of the courts if, for example, it involves certain transactions of foreign states, although such cases are rare. Such an issue is nonjusticiable in light of the constitutional limits of the court's competence "as against that of the executive in matters directly affecting the United Kingdom's relations with foreign states." ${ }_{33}$ Buttes Gas and Oil is the leading case in this category, ${ }^{34}$ standing as a vindication of the separation of powers doctrine between the executive and the judiciary. Second, under the doctrine of Parliamentary supremacy, where there are "proceedings in Parliament" there are known to be "constitutional limits of the court's competence as against

3 I The description of the facts in this case is taken from Smith, "The Problem of the Non-Justiciability of Religious Defamations," $247-48$.

32 See His Honor Judge Cooke's opinion in Khaira v. Shergill [2003] EWHC $4 \mathrm{I} 62$ (ch), paras. 22-25.

33 Ibid., para. 42.

34 Ibid., para. 42 (referencing Buttes Gas and Oil Co. v. Hammer (No 3) [1982] AC 888, 935-37). 
that of Parliament," 35 so that whether one is looking at the doctrine of the separation of powers or that of Parliamentary sovereignty what is distinctive here is that "once the forbidden area is identified, the court may not adjudicate on the matters within it, even if it is necessary to do so in order to decide some other issue which is itself unquestionably justiciable." ${ }^{36}$

The second kind of nonjusticiable case is rather different. It arises if the claim or defense is "based neither on private legal rights or obligations, nor on reviewable matters of public law." ${ }_{7} 7$ This category would cover domestic disputes; disputes where parties transacting did not want to affect their legal relations; and disputes involving issues of international law that did not engage a private right or a reviewable question of public law. Although these are all instances of nonjusticiable cases, they are not necessarily clear-cut. Generally, the court will not decide issues "in the abstract." But if another matter must be decided "which is in itself justiciable," then the court may do so. It is the domain of public law that yields the best known examples. Generally, whenever the court declines to adjudicate on the international acts of foreign sovereign states or to review the exercise of the crown's prerogative in the conduct of foreign affairs, it does so, as the Supreme Court explained in Shergill, $3^{8}$ because "no legal right of the citizen is engaged whether in public or private law." ${ }_{39}$ The reason is, as Cranston J once put it, because "there is no 'domestic foothold," as the Supreme Court in Shergill recounted.4

Nevertheless, the court does adjudicate on these matters if a justiciable legitimate expectation or a right, such as from the European Convention on Human Rights depends on it. ${ }^{\text {I }}$ But the court's assumption of jurisdiction over such matters is not dependent on such public law claims alone because if a private law liability is asserted which depended on the international acts of foreign sovereign states or on the exercise of the crown's prerogative, the court would again adjudicate. Lord Bingham of Cornhill made this clear in the Gentle case in 2008 when he said that, even in areas where the courts have been reluctant to adjudicate, "[t]his is not to say that if the claimants have a legal right the courts cannot decide it." ${ }^{22}$ Clearly, therefore, the domain of nonjusticiability for the courts is much narrower and finite than has hitherto been assumed. Religion per se is not one of them. In fact, even where it is sometimes said that the doctrine of nonjusticiability prevails, such as on issues of international law or matters of crown prerogative, the practice may well be different if there is a legal right to determine.

Internal understandings of religion are, as the Supreme Court of Canada has recognized,43 difficult to adjudicate upon, which is why it is said that the courts should avoid judicially interpreting

35 Prebble v. Television New Zealand Ltd [1995] I AC 32 I.

36 Shergill \& Ors v. Khaira \& Ors [20I4] UKSC 33 , para 42.

37 Ibid., para. 43 .

38 Ibid.

39 Ibid. (referencing R (on the Application of the Campaign for Nuclear Disarmament) v. Prime Minister [2002] EWHC 2777 (Admin); R (on the Application of Al-Haq) v. Secretary of State for Foreign and Commonwealth Affairs [2009] EWHC г9ro (Admin)).

40 Ibid.

4I R (on the Application of Abbasi) v. Secretary of State for Foreign and Commonwealth Affairs [2002] EWCA Civ 1598 .

42 In R (on the Application of Gentle) v. Prime Minister [2008] UKHL 20, para. 8, Lord Wilberforce states that there are "issues which judicial tribunals have traditionally been very reluctant to entertain because they recognize their limitations as suitable bodies to resolve them. This is not to say that if the claimants have a legal right the courts cannot decide it. The defendants accept that if the claimants have a legal right it is justiciable in the courts, and they do not seek to demarcate areas into which the courts may not intrude." See also, the reference to Gentle in Shergill [2014] UKSC 33 , para. 43.

43 Shergill [2014] UKSC 33, para 44, (referencing Bruker v. Marcovitz [2007] 3 SCR 607). The Supreme Court also cited Syndicat Northcrest v. Amselem [2004] 2 SCR 47, para. 44. 
and thus determining, "the content of a subjective understanding of religious requirement" that may arise in the form of an “'obligation,' precept, 'commandment,' custom or ritual." 44 But once again, the determination of this question would depend on what was at stake in terms of rights and interests. As the Supreme Court in Shergill made clear, "this did not prevent them from giving effect to the civil consequences of religious acts" (emphasis added). To take an example, a court cannot enforce a married couple's purely religious obligations to each other, as was made clear in one Jewish divorce case where a husband and wife had reached a religious agreement. Mr. Justice Munby, described the resulting querulous dispute over their agreement in court in terms that, "the basis of her objection is not that the husband has agreed to pay her too little but that she has agreed to pay him too much." 45 The judge's immense frustration here was at having to decide that which could not be decided as a question of fact. This is clear in his words:

How is a secular judge to evaluate the combination of the get and a decree based on the husband's conduct rather than the wife's adultery for a family apparently exercised by the possible religious and social ramifications? How am I to put a price on the cost to the husband of a divorce obtained by his wife against him on the ground of his behaviour rather than a divorce obtained by him on the ground of her adultery? By what standard am I to assess whatever religious or moral duty the husband may have been under to give his wife a get-particularly if he had reason to think she was guilty of adultery?" ${ }^{4} 6$

As he went onto explain, "[t]here are no means by which a secular judge, who may himself be an adherent of the same or a different faith or of no faith at all, can evaluate, let alone attribute some pecuniary value to, something as personal and of such religious significance as a get." 47

Such cases aside, a court can, however, enforce the obligations' "religious nature" as a civil contract once it is "based on the violation of a rule recognized in positive law." ${ }_{48}^{8}$ It is in this way that internal understandings of a religion can be given full legal effect in a court of law, and the distinction between the public and private can be collapsed. This is an innovative and imaginative exercise of the judicial function by secular judges and the Shergill case is an emphatic affirmation of this principle. The Canadian Supreme Court has put it well that "a court is ... not barred from considering a question of a religious nature, provided that the claim is based on the violation of a rule recognized in positive law." 49 Religious questions per se are not, therefore, beyond the purview of the courts. On the contrary the court's adjudicative function suggests that wherever possible it must find ways of resolving issues of a religious nature insofar as this can be done through the enforcement of a civil right or obligation. Once "justiciability" is overcome the rule is an enabling one, not a disabling one, and the public and private domains become illusory for all practical purposes.

44 Ibid., para. 44 .

45 X v. X [200I] EWHC I I (Fam), para I. The get and the get procedure have been described by Wall J in Berkovits v. Grinberg (Attorney-General Intervening) [1995] Fam I42 and again in N v N (Jurisdiction: Pre-Nuptial Agreement) [I999] 2 FLR 745. In the latter case Wall J said, (I) A get, to be valid must be a mutually consensual transaction. The husband must freely deliver the get, and the wife must freely receive it. (2) Only the husband can initiate the get process. (3) A get obtained by compulsion on either the husband or the wife is invalid in Jewish law. N v. N [I999] 2 FLR 745, at 750.

46 Ibid., para. II I.

47 Ibid., para. II 2.

48 Shergill \& Ors v. Khaira \& Ors [20I4] UKSC 33, para. 44.

49 Ibid., para. 44 (quoting Bruker v. Marcovitz [2007] 3 SCR 607, para. I 22). 
Yet, what is remarkable about the Shergill case is the way in which the Court of Appeal below held religious issues to be nonjusticiable per se. The I991 deed was the basis for the setting up of the original Nirmal Kutia gurdwaras in the United Kingdom..$^{\circ}$ The Court was asked to determine whether Sant Jeet Singh was the Third Holy Saint in accordance with the terms of the I99I Deed, whether the doctrines to which he and his adherents subscribed were compliant with the I99I Deed, and whether his personal qualities complied with the religious aims and purposes underlying the I99I Deed. On all three issues, the Court of Appeal held the determination of this question to be nonjusticiable. Mummery LJ in the Court of Appeal took as his starting point the House of Lords case of Buttes Gas and Oil"5 as "the clearest and most authoritative guidance" for the way that "a line is drawn between justiciable and nonjusticiable issues." The dispute in that case, however, had nothing whatsoever to do with religion. It concerned the boundary between the territory of three gulf states upon which the parties' off-shore drilling rights depended. In Buttes Gas and Oil, Lord Wilberforce enunciated a general principle in English law of "judicial self-restraint or abstention," which he said was a principle of law "inherent in the very nature of the judicial process." ${ }^{2}$ In Shergill, The Supreme Court noted that this case "is so well known," 53 because it was about the "act of state" doctrine, and, as Lord Wilberforce cautioned, the "possibility of embarrassment in our foreign relations" with the gulf states was such that there could be "no judicial or manageable standards by which to judge those issues." 54 For this reason the court could not risk going into "a judicial no man's land" 55 especially given the institutional constraints upon the judiciary in a case such as this. Mummery LJ in the Court of Appeal was wrong to equate the two kinds of judicial restraint on grounds that "the acts complained of were guided by religious beliefs whose justification was incapable of objective assessment." ${ }_{56}$

The distinction between normative nonjusticiability, affecting matters that a court does not possess the adequate tools to review, and institutional nonjusticiability, which arises over matters which a court can, but would refrain from reviewing, because of institutional constraints, is a useful one that the Court of Appeal could have adopted. Buttes Gas and Oil was a case of institutional

$50 \quad$ Ibid., para. 37.

5 I Buttes Gas and Oil Co. v. Hammer (No.3) [I982] AC 888 (Lord Wilberforce J).

52 Shergill \& Ors v. Khaira \& Ors [2OI4] UKSC 33, para. 38.

53 Ibid., para. 38.

54 In Shergill, the Supreme Court explained that

Lord Wilberforce's reference to judicial and manageable standards was a quotation from the decision of the Fifth Circuit Court of Appeals in the United States litigation between the same parties upon substantially the same issues. That was in turn based on the celebrated decision of the United States Supreme Court in Underhill $v$. Hernandez I 68 US 250 (I897) about the act of state doctrine. The reason why the Fifth Circuit Court of Appeals regarded the issue as non-justiciable was not that judges were incapable of deciding questions of international law. Nor was that why Lord Wilberforce agreed with them. Quite apart from the fact that he was himself an international lawyer of some distinction, he points out at p $926 \mathrm{~F}$ that English courts had on a number of occasions decided issues about the international boundaries of sovereign states "without difficulty." The issue was non-justiciable because it was political. It was political for two reasons. One was that it trespassed on the proper province of the executive, as the organ of the state charged with the conduct of foreign relations. The lack of judicial or manageable standards was the other reason why it was political.

\footnotetext{
Ibid., para. 40.

55 Ibid., para. 38.

56 Ibid., para. 39.
} 
nonjusticiability and therefore irrelevant to the matter of nonjusticiability of religion. However, because Buttes Gas and Oil concerned the acts of sovereign states, it had "not been governed by law but by power politics," ${ }^{7}$ and for this reason "[i]t is difficult to imagine that such a conclusion could have been reached in any other context than the political acts of sovereign states, for the acts of private parties, however political, are subject to law" ${ }^{8} 8$ (emphasis added). Where private parties are concerned, they are "answerable to municipal courts of law having jurisdiction over them." 59 These municipal courts will be "applying objective, external legal standards." 60 Yet the Supreme Court could have put it more simply. It could have said that making private law religious disputes a "judicial no-man's land" would mean that a nonjusticiability decision in private law basically constitutes ruling in favor of the defendant, and it does so on entirely arbitrary grounds without proper justification.

\section{THE JUSTICIABILITY OF RELIGION PRIOR TO SHERGILL}

As mentioned, in the United Kingdom there are two lines of cases that precede and inform Shergill. These are the nineteenth-century cases on Scottish churches and the cases on succession to religious office. Although both lines of cases influence the Shergill decision, it is the line of nineteenth-century Scottish church cases that provide more of the basis from which the court derives its holding. The Supreme Court in Shergill does this by resurrecting what is a forgotten tradition in judicial decision making: confronting difficult questions of canonical religious disagreement and resolving them. It is necessary, first, therefore, to discuss the religious successor cases; the nineteenth-century Scottish cases; and the role of private and public law in justiciability of religion. From these discussions, it is possible to assess the full impact of Shergill and draw some final conclusions.

\section{The Religious Successors Cases}

In the field of UK public law, the most famous example of the nonjusticiability of religious issues arising in the context of the suitability to office of a religious incumbent is the 1992 case of Wachmann, ${ }^{6 \mathrm{I}}$ now almost a quarter of a century old. It is, as the Supreme Court in Shergill ${ }^{62}$ reminded us, a much-misunderstood case. It has sown the seeds of confusion in appearing to suggest that, as a matter of public law, religion is not justiciable before the courts. In Wachmann, the chief rabbi of the United Kingdom decided that an applicant for the rabbinate was not religiously and morally fit to hold that office. ${ }^{63}$ The rabbi's status and legitimacy, in the sense of his religious

57 In Shergill, as the Supreme Court explained, the Buttes Gas and Oil case was one where, "the dispute arose out of the way in which the four states concerned had settled the issue of international law by a mixture of diplomacy, political pressure and force in a manner adverse to the interests of Occidental Petroleum. Occidental wished to obtain a judicial decision that that settlement had been the result of an unlawful conspiracy" and this judicial settlement the Court could not provide against the background of these facts. See ibid., para. 40.

58 Ibid., para. 40.

59 Ibid.

60 Ibid.

6I R v. Chief Rabbi of the United Hebrew Congregations of Great Britain and the Commonwealth, Ex p Wachmann [1992] I WLR I036.

62 Shergill \& Ors v. Khaira \& Ors [20I4] UKSC 33, para. 58.

63 Since, however, the case did not involve property rights for dissenting members of religious charities it is not discussed by Robert Meakin in his clear and concise analysis of how property can continue to be held by those 
suitability and credentials, were put in question before the secular courts. This did not, however, raise an issue of public law that was amenable to judicial review. ${ }^{64}$ The claim in Wachmann was not presented as a challenge to the contractual jurisdiction of a voluntary association. Had it been so presented, the court would have had jurisdiction to consider questions of ultra vires and determine allegations of breaches of natural justice. ${ }^{65}$ Rather, the case presented a question regarding legitimacy and succession that turned solely on religious doctrine and did not implicate a private right.

The 1999 case of Varsani $v$. Jesani ${ }^{66}$ is altogether more instructive and the nearest that one comes to the Shergill type of scenario. In the words of Meakin, the situation here was one "where the religious constitution does not cater for doctrinal developments." ${ }^{67}$ Prior to Varsani, the nineteenth-century decisions had established that "unless religious charities have an express power to amend their doctrines or provide for schism, then the original religious doctrine must apply to the trusts relating to the property." ${ }^{68}$ In the nineteenth-century cases, the task at hand for the court was determining how to enforce the existing trusts. Following Varsani, the courts have been more concerned with how to give effect to the spirit of the gift. The case concerned the jurisdiction of the court to make a scheme for the division of the funds of a religious charity set up by a declaration of trust in 1967 for the promotion of the Hindu sect of Swaminarayan and according to the teachings and tenets of Muktajivandasji. The dispute arose over the use of a temple in London that was held in trust for this Hindu sect following allegations made in I984 of misconduct raised against the successor whom Muktajivandasji had nominated before his death in I979. This led to a schism in the community, whereby the temple could not be used by all for worship in London.

When issues of identification, status, and legitimacy arose, the majority of the community accepted the authority of the successor. A minority thought that he had disqualified himself by his behavior. The Court of Appeal in Varsani held that the matters arising were clearly justiciable given the jurisprudence established in the nineteenth century cases of Craigdallie, AG v. Pearson, and the Free Church. ${ }^{69}$ However, Morritt LJ propounded a more expansive doctrine for the court when stating that, "[t]he relevant test in this case is now whether the original purpose has ceased to provide a suitable and effective method of using the property, regard being had to the spirit of the gift." 70 Meakin in his analysis of this case aptly concludes his discussion with the observation that "[i]n the 2Ist century, members of religions are increasingly active in asserting their views on doctrinal issues" and that "[t]he Varsani case provides a charter for dissenting religious members to assert their rights over church property." ${ }^{71}$

professing new doctrinal beliefs different from those in the original religious constitution or charitable trust and company. Meakin, "Property Rights for Dissenting Members of Religious Charities."

64 This was made clear by the Supreme Court in Shergill \& Ors v. Khaira \& Ors [20I4] UKSC 33, para. 58.

65 As the Supreme Court explained in Shergill, ibid, para. 58, this would have followed on from the principles established in Long v. Bishop of Cape Town (I863) 4 Searle I62 PC, I76; R v. Imam of Bury Park Mosque, Luton, Ex parte Sulaiman Ali, CA I2 May I993 QB COF 9I/I247/D (Times, 20 May I993) (Roch LJ citing Lee v. Showmen's Guild of Great Britain [1952] 2 QB 329, 342 (Denning LJ)); Brentnall v. Free Presbyterian Church of Scotland I986 SLT 47I.

66 Varsani v. Jesani [1999] Ch 2 I9.

67 Meakin, "Property Rights for Dissenting Members of Religious Charities," 59.

68 Ibid.

69 Shergill \& Ors v. Khaira \& Ors [20I4] UKSC 33, para 55.

70 Varsani v. Jesani [1999] Ch 219, 233.

7 I Meakin, "Property Rights for Dissenting Members of Religious Charities," 68. A public law issue nevertheless has to be in contention, which is why issues of religious doctrine could not be considered in relation to the status of a 


\section{The Nineteenth-Century Scottish Cases}

It was in the nineteenth century that the justiciability of religious questions by a secular court of law was, as the Supreme Court in Shergill reminded us, first established..$^{72}$ Craigdallie v. Aikman ${ }^{73}$ in ${ }_{18} 8{ }_{3} 3$ is the first of these cases where Lord Eldon held that in the event of a division within a voluntary religious body, the property held for the purposes of the association will go to the part of the body that adheres to its fundamental religious principles. This was the principle both of English law and of Scots law. Lord Eldon, four years later, in the second English case of Pearson established that, whenever congregations "become dissentient among themselves," then "the nature of the original institution must alone be looked to as the guide for the decision of the Court" and that it is altogether "beyond the reach" of the Court "to refer to any other criterion." 74 In what became the third of the nineteenth-century cases, the rule in Craigdallie v. Aikman was reaffirmed by the House of Lords before a Bench of seven Law Lords in the Free Church Case in 1904. ${ }^{75}$ Taking their lead from Craigdallie v. Aikman, these cases established the principle that the courts could intervene to make decisions in matters of religious faith. The courts were required to look at and to decipher and construe the trust deed or other agreement that underlies a religious institution. So well established was this rule that recently in 20II Lord Drummond Young, in Smith $v$. Morrison, gave a careful historical analysis of the development of these principles from over a century ago. ${ }^{76}$ His Lordship's erudite analysis of the cases in the Inner House of the Court of Session in Scotland concluded with the observation that, "in every case ... it is the trust deed or other agreement that determines what are the fundamental principles on which the congregation associated." 77

\section{The Role of Private and Public Law in Justiciability of Religion}

In his recent book Constitutionalism and Religion, Francois Venter, states that "[c]ourts in constitutional states do not as a matter of course assume the jurisdiction to adjudicate on theological matters or religious dogma." ${ }^{8}$ Indeed, as an example of Venter's proposition, in one UK case Munby J. declared that "[r]eligion ... is not the business of government or of the secular courts.... The starting point of the law is an essentially agnostic view of religious beliefs and a tolerant indulgence to religious and cultural diversity. ... It is not for a judge to weigh one religion

priest in the 2003 case of Blake v. Associated Newspapers Ltd [2003] EWHC 1960, as there was no public law issue involved. Here the court stayed an action for defamation by Mr. Blake against the publisher of the Daily Mail for describing him as a "self-styled" or "imitation" bishop, after he had relinquished his status as a priest within the Church of England. He had subsequently established another organization where he had then been consecrated as a "bishop." Blake is discussed in greater detail later in the article.

72 Although the Supreme Court referred to four cases, there were many more at the time. See Rivers, The Law of Organized Religions, chapter 3.

73 Craigdallie v. Aikman (I8I3) I PC Dow I, I4-I6, (cited in Shergill [20I4] UKSC 33, para. 5I).

74 Attorney General v. Pearson (I8I7) 3 Mer 353, 400-OI, 36 ER I36, I50 (cited in Shergill [2014] UKSC 33, para. 5I).

75 General Assembly of the Free Church of Scotland v. Overtoun [1904] AC 51 5, 7 F (HL) I.

76 Smith v. Morrison (2OII) SLT I2I3.

77 Ibid., para, IOI (cited Shergill [2014] UKSC 33, para. 52).

78 Venter, Constitutionalism and Religion (Cheltenham: Elgar Publishing, 2015), I72. 
against another. All are entitled to equal respect." 79 Lord Wilberforce has similarly declared in a UK Supreme Court case that religion is a "judicial no-man's land." 80

Yet discussions of church-state cases often overlook the normative distinction between the domain of public law and the domain of private law by conflating the two categories. At best this leads to an oversimplification of the issues. At worst, it causes complete confusion about what can and what cannot be adjudicated. The correct position, which distinguishes public law and private law questions, is as follows: where civil rights and interests are to be determined on the basis of the general law of the land (public law), there is no limit to what a secular court can decide, provided that the evidence before the court is capable of objective assessment. The secular court's ability to adjudicate questions of private law is different on account of the "autonomy of religious institutions," to use the US Supreme Court's language in Catholic Bishop of Chicago. ${ }^{8}$ I Adjudicating private law issues or disputes internal to the governance of a religious organization would mean secular court interference with the autonomous operation of religious institutions. Secular courts should, therefore, be hesitant to adjudicate issues of purely private law. Thus, a doctrine of justiciability that recognizes the distinction is important because, as Venter points out, as difficult as issues of religion are for the courts they "do reach the courts" all the same. ${ }^{82}$

In the United Kingdom, the distinction between public law and private law was considered in $R(E) v$. Governing Body of JFS [20IO] 2 AC 728 (hereafter JFS), one of the most important cases of recent years. Here the Supreme Court confronted the religious basis of the admissions policy of the Jewish Free School. This policy gave priority to children recognized as Jewish by the Office of the Chief Rabbi. The Court held that the policy offended against the law of the land as enshrined in the Race Relations Acts because of the racial/ethnic way in which Jewishness was defined for the purposes of the admission policies. The chief rabbi of Orthodox Judaism recognizes

79 See Munby J in Sulaiman v. Juffali [200I] EWHC 556 (Fam), at 47, where the full paragraph reads as follows:

Although historically this country is part of the Christian west, and although it has an established church which is Christian, I sit as a secular judge serving a multi-cultural community of many faiths in which all of us can now take pride, sworn to do justice to all manner of people. Religion-whatever the particular believer's faith-is no doubt something to be encouraged but it is not the business of government or of the secular courts. So the starting point of the law is an essentially agnostic view of religious beliefs and a tolerant indulgence to religious and cultural diversity. A secular judge must be wary of straying across the wellrecognised divide between church and state. It is not for a judge to weigh one religion against another. All are entitled to equal respect, whether in times of peace or, as at present, amidst the clash of arms.

80 The phrase was used by Lord Wilberforce in the boundary dispute case involving the territory of three Gulf states of Buttes Gas and Oil Co. v. Hammer (no. 3) [1982] AC 888, which, although not a case involving religion, was cited with approval by Mummery LJ when His Lordship declined jurisdiction to hear the appeal in Shergill \& Ors v. Khaira \& Ors [2014] UKSC 33, paras. 38-39.

8 I National Labor Relations Board v. Catholic Bishop of Chicago, 440 U.S. 490 (I979) (holding that the domestic authorities could not disregard the bishop's will by recognizing a trade union for teachers from Catholic schools). The general concept of the autonomy of religious institutions in church-state relations has been affirmed by the US Supreme Court more recently in Hosanna-Tabor Evangelical Lutheran Church, where the Court applied the "ministerial exception" doctrine, and held that the provisions of labor law were not applicable to employees of religious institutions, without regard to whether the employees were laity or clergy. Hosanna-Tabor Evangelical Lutheran Church and School v. Equal Employment Opportunity Commission, I32 S. Ct. 694 (20I2). European courts, including the Grand Chamber of the European Court of Human Rights, have also recognized the autonomy of religious institutions. See Sindicatul "Păstorul cel Bun" v. Romania 2330/09 Grand Chamber Judgment [20I3] ECHR 646 (o9 July 2013), para. I 27. 
as Jewish (I) anyone born of a Jewish mother and (2) anyone who has had an Orthodox conversion to Judaism. However, other branches of Judaism, notably Liberal Judaism, also recognize as Jewish (2) anyone whose father is Jewish, even if the mother is not, and (2) anyone who has had a Liberal conversion to Judaism. Given that there are Liberal Jews whose status is not recognized by the chief rabbi, the issue before the Court was a matter of doctrinal dispute. The members of the Supreme Court took cognizance of the rules that the chief rabbi was applying to the doctrinal meaning of Jewishness, but they differed on whether the rules were directly or indirectly discriminatory for the purposes of the Race Relations Acts. The situation before the court was complicated by the fact that Jews (and Sikhs for that matter) are regarded as racial groups for the purposes of the Race Relations Act 1976, while other religious groups are not. This is not without practical significance given that the question before the Court was simply whether the admissions policy of the Jewish Free School had discriminated against the excluded boy on racial as much as on religious grounds. To this, the question whether or not the boy was halachically Jewish according to Orthodox Judaism was peripheral, given that he did not have to be halachically Jewish in order to attract the provisions of the Race Relations Act 1976.

In the JFS case, Lord Hope of Craighead explained how the courts would be wary of straying across the divide between church and state, but "the divide is crossed when the parties to the dispute have deliberately left the sphere of matters spiritual over which the religious body has exclusive jurisdiction and engaged in issues that are regulated by the civil courts." ${ }^{8} 3$ Lord Hope drew attention to the public law nature of the dispute when observing how, "[i]t is accepted on all sides in this case that it is entirely a matter for the Chief Rabbi to adjudicate on the principles of Orthodox Judaism. But the sphere within which those principles are being applied is that of an educational establishment whose activities are regulated by the law that the civil courts must administer." ${ }_{4}$ In the JFS case, there was no issue as to "justiciability" because to say that the educational sphere was one that was regulated by law was not to acknowledge that the Court's jurisdiction was in contention. In fact there was no question of "justiciability" whatsoever before the Supreme Court in the $J F S$ case. What this suggests is that matters spiritual cease to be purely private and enter the public domain giving the secular courts jurisdiction over them to decide disputed issues of fact once the law of the land is engaged. In the JFS case this was the antidiscrimination law of the land. In the Shergill case this was the much more mundane-yet all the more irresistible-question of how trust law doctrines applied to the administration of trust property held by religious institutions. The distinction between the private and public spheres is collapsed and rendered illusory. The fact that such institutions belong to a religion outside the Judeo-Christian tradition not entirely familiar to judges of the English courts was entirely irrelevant to the jurisdiction that the civil courts were required by law to assume. How this was done is the question to which we now turn.

\section{THE IMPACT OF SHERGILL}

The Shergill case has significantly unsettled the reigning notion among judges that matters of theology and religious doctrine are nonjusticiable,${ }^{85}$ an understanding that grew from the tendency to overlook the normative distinction between the public law of the land and private law internal to

$83 \mathrm{R}(\mathrm{E}) \mathrm{v}$. Governing Body of JFS [2010] 2 AC 728, paras. I 57-60.

84 Ibid., para. I60.

85 This assumption of nonjusticiability has been so prominent that a strange irruption of the doctrine has taken place since the time of the Blake case in 2003 , as discussed above, and it has created a curious instability in the law, 
the autonomy of religious institutions. Because this distinction had long been obfuscated, at the time of the Shergill litigation it was accepted orthodoxy for the courts to shy away from the consideration of religious issues. ${ }^{86}$

To get a sense of how powerful this orthodoxy was, one need look no further than the 2or I case of Shergill v. Purewal \& Anor, ${ }^{87}$ in which Mr. Shergill brought a suit in libel against Mr. Purewal. Mr. Purewal had published in a newspaper three articles in which he alleged that the Third Holy Saint, Sant Jeet Singh Ji Maharaj, was "improperly passing himself off as the heir" after the Second Holy Saint had died suddenly in 2003 and had left no "named successor nor a will." Mr. Shergill considered this allegation to be libelous given "that a Bhekh or conclave of senior priests had appointed as successor a holy man now styled as His Holiness Sant Baba Jeet Singh Ji Marahaj," thus ensuring his proper and legitimate appointment as the Third Holy Saint of the order of the Nirmal Kutia Johal. ${ }^{88}$

In Shergill v. Purewal \& Anor, Levenson LJ recounted how, given that the claim was, "intimately connected with allegations concerning the circumstances in which a successor is said to have been appointed," the action had to be stayed because "it would require the court to determine religious doctrinal disputes and the extent to which religious procedures have been observed." 89 Yet, as Levenson LJ quipped during the proceedings, "[n]o step was then taken to resolve the issue of justiciability." 90 The court itself could not proceed any further to determine the issues arising from the alleged libelous publication because there was a "self-denying ordinance" whereby "the issues fell 'within the territory which the courts ... will not enter." ${ }_{91}$ What is remarkable is that this position was taken despite the courts acknowledging that private rights and interests were intrinsically at stake in that "Mr Shergill is also involved in proceedings to obtain title to premises, or gurdwaras, used by this sect of the Sikh religion in this country." ${ }^{2}$ It is therefore important to recognize that it is against this background that Mummery LJ in the Court of Appeal heard the Shergill case in 20I2. By that stage, however, the die had been cast. Religious issues were beyond the purview of the courts to examine. Shergill $v$. Purewal \& Anor preceded the Supreme Court judgment in Shergill \& Others $v$. Khaira \& Others by just three years. Yet today the court's decision in Shergill $v$. Purewal \& Anor, that it had no jurisdiction to determine religious disputes, looks decidedly archaic and misbegotten.

which has oscillated between regarding religious disputes as a no-go area, to regarding them as entirely irrelevant to the determination of civil rights and interests.

86 In his book Ecclesiastical Law, Mark Hill QC states that "a self-denying principle of non-interference by which the judiciary decline to enter into questions concerning the internal affairs of religious organisations is now wellestablished.” Hill, Ecclesiastical Law, 3 rd ed. (New York: Oxford University Press, 2008), ch. I, para. 43. Hill later adds, "The courts have repeatedly expressed their unwillingness to trespass into matters of doctrine but will do so where necessary." Ibid., ch. I, para. 44. Confusion has also been caused by R v. Chief Rabbi of the United Hebrew Congregations of Great Britain and the Commonwealth ex p. Wachmann, which concerned an Orthodox rabbi dismissed from his post following a declaration by the chief rabbi that he was unfit because of his adulterous relationship with a congregant. Simon Brown J wrote, "The court is hardly in a position to regulate what was essentially a religious function - whether someone is morally and religiously fit to carry out the spiritual and pastoral duties of his office. The court must inevitably be wary of entering so self-evidently sensitive an area, straying across the well-recognised divide between church and state." [1992] I WLR I036, para. I042H-3A. Shergill v. Purewal \& Anor [20II] EWCA Civ 8I 5 .

88 Ibid., para. 2.

89 Ibid., para. I.

90 Ibid., para. 5 .

9 I Ibid., para. I.

92 Ibid., para. 2. 
This is because the Supreme Court in Shergill \& Others v. Khaira \& Others has now taken a different and altogether more enlightened approach. It is important to first note how the Supreme Court distinguished two cases that had long supported the nonjusticiability of religion by obfuscating the private law/public law distinction. 93 First, the respondents in Shergill \& Others $v$. Khaira \& Others relied on Wachmann for the proposition that the court did not have jurisdiction to determine the succession of the Third Holy Saint, just as the Wachmann court lacked jurisdiction to determine the complainant rabbi's fitness for office. In response, the Supreme Court promptly pointed out that in Wachmann, no question of public law was involved, and so that case did not support such a contention. ${ }^{94}$ Put simply, "[t]he case is not an authority for a proposition that the legality of such disciplinary proceedings is not justiciable." 95 Thus, Wachmann might stand for the proposition that cases raising purely private issues within the realm of religious autonomy are not justiciable, but where a question of public law was at issue, Wachmann would not control.

The Supreme Court also rejected the Blake Case, which had long supported the nonjusticiablity of religion doctrine. In Blake, the court refused to hear the complainant's claim because "the case raised questions of doctrine and ecclesiology: the question was whether [Blake] was a bishop or merely a self-styled bishop." 96 The Supreme Court in Shergill rejected the Blake court's reasoning, explaining that, although this was a case which involved questions over Blake's identification and legitimacy, these were not questions which were based solely on a private law right or interest; rather, the question before the court was one of public law at large, namely the tort of defamation. Thus, the Shergill court wrote of the Blake decision, "We do not think that the [Blake] court was correct to refuse to adjudicate on that issue on the ground that it was nonjusticiable. The claim was a civil claim in tort and the court will enter into questions of disputed doctrine if it is necessary to do so in reference to civil interests." 97

Thus, Shergill was not a purely private case like Wachmann, and Blake was wrongly decided, which created an opening for the court to look at the issues of religious doctrine in order to adjudicate the public law issue in the Shergill case. While Shergill raised issues of religious legitimacy, like Wachmann and Blake, it was also different because in Shergill those who opposed the control of the Third Holy Saint, did so over a question of trust property, even though it raised the religious question of whether the succession of the Third Holy Saint to the institution of the Nirmal Kutia Johal in India was contrary to established religious precepts of that order.

93 The respondents had actually referred to the two judgments of Gray J in Blake v. Associated Newspapers Ltd, [2003] EWHC 1960, and Simon Brown J in R v. Chief Rabbi of the United Hebrew Congregations of Great Britain and the Commonwealth, Exp Wachmann, [1992] I WLR 1036, in support of their contention that the dispute in this case was nonjusticiable. See Shergill \& Ors v. Khaira \& Ors [2014] UKSC 33, para. 57.

94 The Supreme Court went on to explain how, had the case arisen in Scotland, it would have been determined on the religious issues regardless of the lack of a public law dimension to the case because, "the wider scope of the supervisory jurisdiction of the Court of Session, which extends to those who exercise a jurisdiction conferred by private contract, would have allowed the challenge to be in the form of an application for judicial review as an alternative to a claim based on contract." Shergill \& Ors v. Khaira \& Ors [20I4] UKSC 33, para. 58. This proposition is clear from West v. Secretary of State for Scotland $\mathrm{I}_{992} \mathrm{SC}_{385}$, Lord President Hope at 399-400 (cited in Shergill \& Ors v. Khaira \& Ors [2014] UKSC 33, para. 58). Shergill \& Ors v. Khaira \& Ors [2014] UKSC 33 , para. 58.

96 Ibid., para. 57.

97 Ibid. However, the Court continued, "the problem that such defamation claims face, which will usually doom them to failure, is that they raise issues of religious opinion on which people may hold opposing views in good faith. The expression of such views without malice is likely to be protected by the defence of honest comment-what used, until Joseph v. Spiller [20II] I AC 852, to be called fair comment." Ibid. 
In addressing the trust aspect of the Shergill case, the court looked to the oft-neglected nineteenth-century jurisprudence dealing with the schism of the Scottish Presbyterian churches at that time, which a hundred years ago established that the courts may legitimately ascertain the foundational and essential tenets of a faith in order to identify who was entitled to the property. To the consideration of this jurisprudence, we now finally turn because it confirms how the public law and private law realms are fundamental to whether disputes are to be categorized as "justiciable" or "nonjusticiable." The Supreme Court in Shergill resurrected the traditional nineteenthcentury principles of justiciability, making them applicable in the modern world, by empowering the secular courts to deal with religious questions where private rights created by public law are at stake. ${ }^{98}$ Referring to Craigdallie v. Aikman and the Free Church case of 1904 it reminded us of how the importance of looking at the nature of the original institution alone as a guide for the decision of the Court was such that this, "rule has been applied since then." 99 But the court went even further. It explained that what this means is that "the law looks to the fundamental principles and essential standards of the body" and not to "minor matters of administration and minor changes in doctrine" when it sets itself the task of ascertaining the scope of the trust. ${ }^{100}$

The Supreme Court's decision in Shergill is both an affirmation of the 1992 judgment of the Court of Appeal in Varsani v. Jesani (discussed above) and an advancement on it. It is now emphatically clear that the courts could not ignore, but had to be apprised of, matters of belief, doctrine, and church government, stipulated in the trust deed or other agreement. Nowhere is this clearer than in the 1952 unreported Scottish case of Mackay $v$. Macleod ${ }^{\mathrm{Ior}}$ (which Lord Drummond Young had carefully analyzed in his 20I I judgment ${ }^{\mathrm{IO} 2}$ ), where Lord President Cooper had considered a dispute involving a competition between two parties, each claiming to be the beneficiaries entitled to certain trust property, and resulted in Lord President's unequivocally declaring that

in such a case it is the duty of the Court to take cognisance of relevant matters of belief, doctrine and church government for the purpose, but only for the purpose, of informing themselves as to the essential and distinguishing tenets of the Church in question, and of discovering the differences, if any, which can be detected in the principles to which the competing claimants respectively profess adherence (Supreme Court's emphasis). ${ }^{\text {.03 }}$

In Shergill, when the Supreme Court considered this opinion, ${ }^{\mathrm{10}}{ }^{\mathrm{i}}$ it was left in no doubt that, "this clear line of authority contradicts the idea that a court can treat a religious dispute as nonjusticiable where the determination of the dispute is necessary in order to decide a matter of disputed legal right." ${ }^{\text {Iо5 }}$ This did not mean that a secular civil court should determine the truthfulness of a religious tenet. In the Free Church case Lord Davey in the House of Lords in 1904 had made it clear that the civil courts do not have the right "to discuss the truth or reasonableness of any of the doctrines of [a] religious association." ${ }^{\circ 06}$ Lord Davey then added, however, that "[t]he more humble,

98 Smith v. Morrison 20I I SLT I 2 I3, paras I I3-I6 (cited in Shergill \& Ors v. Khaira \& Ors [20I4] UKSC 33, para. 52.

99 Shergill \& Ors v. Khaira \& Ors [2014] UKSC 33, para. 52.

Ioo Ibid.

IOI Mackay v. Macleod (IO January I952) (unreported).

IO2 Smith v. Morrison [20II] SLT I2I3, para. II 8.

IO3 Ibid.

Io4 Shergill \& Ors v. Khaira \& Ors [20I4] UKSC 33, para. 52.

I05 Ibid., para. 53.

I06 Free Church of Scotland v. Overtoun [I904] AC 5I5 (I904 7 F (HL) I), at 644-45. 
but not useless, function of the civil Court is to determine whether the trusts imposed upon property by the founders of the trust are being duly observed." I07

The Supreme Court in Shergill went further than these earlier cases in two respects. First, since property rights were involved the Court held that the Third Holy Saint's power, in the person of Sant Jeet Singh Ji Maharaj, to appoint and dismiss trustees may depend on matters, which could just as well involve issues of doctrinal faith such as

what are the fundamental tenets of the First Holy Saint and the Nirmal sect, (ii) what is the nature of the institution at Nirmal Kutia in India, (iii) what steps or formalities were needed for a person to become the successor of the First Holy Saint, and (iv) ... whether the teachings and personal qualities of Sant Jeet Singh comply with the fundamental religious aims and purposes of the trust. ${ }^{108}$

The Supreme Court held that these matters were open to the High Court, as a court of first instance, to examine as matters of objective fact.

Second, the Supreme Court held that "the principles established in the church cases apply equally to other religions." ${ }^{\text {го }}$ Indeed, in Hasanali v. Mansooraliп just after the Second World War, when an issue arose regarding the validity of the appointment of a successor to the leader of the Muslim Ismailia Shia sect in the Central Provinces in India, the Privy Council had been able to conclude that the predecessor leader had made a valid declaration marking out his successor because it had been able to examine the tenets of the sect and the surviving evidence of what had occurred on the day on which the former leader died. ${ }^{\text {II }}$ This case is the clearest example of how it is quite possible for a secular court to determine "the issue of succession to holy sainthood" on grounds "of establishing religious usage by analysing evidence, or by finding facts on the balance of probability ... or by ascertaining the wishes of a voting majority." Shergill emphasized the value in modern times of this jurisprudence where, "the immigrations of the $20^{\text {th }}$ century have diversified the religious landscape of the United Kingdom" so that today, "the principles of the church cases have been applied equally to other religious communities in this country." ${ }^{113}$

I07 Ibid.

Io8 Shergill \& Ors v. Khaira \& Ors [20I4] UKSC 33, para. 59. The Supreme Court also held that "there is a strong case for saying that expert evidence should be permitted" for the resolution of these questions. See ibid., para. 60.

I09 Ibid., para. 54 .

I Io Hasanali v. Mansoorali (Privy Council Appeal No 79 of I945) (unreported, I December I947). In my earlier short analysis of the Shergill decision, I indicated that Hasanali was unreported (see, Juss, "Back to the Future," I99nI 5). I had based this on the observation of the Supreme Court judgment itself, which had recorded the decision as being unreported. It is in fact reported in Law Reports (Indian Appeals) vol. 75 (I947): I. This case is further considered and followed in the decision of the Supreme Court of India reported in Sardar Syedna v. State of Bombay, I962 Supp. 2 SCR 496 (holding the Bombay Prevention of Excommunication Act of 1947 unconstitutional because it violated Articles 25 and 26 of the Constitution of India.) The Hasanali decision was further noted in a later decision of the Supreme Court in 2005 (2) SCC 673).

I I Shergill \& Ors v. Khaira \& Ors [20I4] UKSC 33, para. 54.

I 2 Shergill v. Khaira \& Ors [20I2] EWCA Civ I 582 (O2 October 20I2), para. 7I (Mummer LJ).

II3 Shergill \& Ors v. Khaira \& Ors [20I4] UKSC 33, para 55. See Jeremy Cliffe's recent groundbreaking paper, "Britain's Cosmopolitan Future: How the Country is Changing and Why Its Politicians Must Respond," Policy Network, May I4, 20I5, http://www.policy-network.net/publications/4905/Britains-CosmopolitanFuture. See Lorenzo Zucca, Law, State, and Religion in the New Europe: Debates and Dilemmas (Cambridge: Cambridge University Press, 2012), where consideration is given to the conflict between law and religion in Europe, and an analyses undertaken of the role played by courts in adjudicating conflicts of rights to religious freedom and other rights. See also, Lorenzo Zucca, A Secular Europe: Religion in the European 
This then is where the ultimate importance of the Shergill decision lies because it shows a willingness from the highest judicial tribunal in the land to consider issues of belief, doctrine, and church government arising from non-Christian religions, when previously such cases were almost entirely those of Christian religions. The courts are evidently willing to determine such questions notwithstanding the relative unfamiliarity of the judges with the practices and doctrines of non-Christian communities. This is going to be significant in the years to come given the large and ever-increasing number of cases now being lodged by non-Christian religions before the courts. The case-law will develop accordingly, with a rich tapestry of issues covering rights, property, and doctrinal disputes being readily confronted by the courts.

How precisely, however, will the secular courts in the future determine "a question of a religious nature" from other non-Christian religions? The Supreme Court gave two distinct examples which are worth noting because of the insights that these provide into the judicial function. ${ }^{\mathrm{I} I} 4$ First, when the governing bodies of religious voluntary associations obtain their powers over their members by contract, they must act within the powers conferred by the association's contractual constitution. Failure to do so will render its actions ultra vires and allow a party to invoke the jurisdiction of the courts. One example of this is Barker $v$. O’Gorman, ${ }^{115}$ where the governing body of a religious voluntary association sought a union with another religious body which its constitution did not allow. The proposed union was between the Methodist Church and the Church of England by virtue of a private Act of Parliament, the Methodist Church Union Act I929. The challenge to jurisdiction was on the ground that the Methodist Conference had no power to vary the doctrinal standards of the former church. Yet it still led the Supreme Court to hold that the principles of ultra vires were the same whether one was dealing with an act of Parliament (such as the Methodist Church Union Act I929) or a contract arising from a voluntary association's contractual constitution. ${ }^{\text {II } 6}$ The issues were "justiciable" notwithstanding the need by the court to interpret a private Act of Parliament. The court would simply avoid delving into the precise theological controversy. ${ }^{117}$ This is a significant boost to the court's power to adjudicate religious questions because one of the reasons why church unions were effected through private Acts in Parliament was that an act settles potential arguments about whether or not a particular union is permitted by the relevant trust deeds by simply overwriting them. ${ }^{\text {I } 8}$

A second example is where the irregularity is not one of procedure alone, but goes to the honesty and integrity of the proceedings complained of. A member of a religious association who is dismissed or otherwise subjected to disciplinary procedures may invoke the jurisdiction of the civil courts if the association acts ultra vires or breaches in a fundamental way the rules of fair

Constitutional Landscape (Oxford: Oxford University Press, 20I2), where Zucca propounds the thesis that the secular state should today be understood as a reconciliation of diversity in European society.

II 4 Shergill \& Ors v. Khaira \& Ors [20I4] UKSC 33 , para. 47.

II 5 Barker v. O'Gorman [I97I] Ch 2I5.

II6 Shergill \& Ors v. Khaira \& Ors [20I4] UKSC 33, para. 47.

I 7 In passing it may be added that the Methodist Church subsequently gained power to vary its doctrinal standards under the Methodist Church Act 1976, but that, of course, was after Barker.

II 8 The classic case is the United Reformed Church Acts 1972-2000. Here the initial union was between the Presbyterian Church of England (which broadly follows the Calvinist/Reformed tradition) and the vast majority of the Congregational Church in England (which in its theology is much less confessional). The union had to braid and interweave together two very different forms of church government and two quite different styles of doing theology. Once the Act of Parliament was passed there could be no further arguments about whether or not the various trustees, in agreeing to the union, had departed from any foundational principles that the trusts were obliged to hold. 
procedure. Once again, just because the cause of the disciplinary procedure is a dispute about theology or ecclesiology it does not mean that the jurisdiction of the courts is excluded. In the words of the Supreme Court in Shergill, "[ $\mathrm{t}]$ he civil court does not resolve the religious dispute" but rather, "[i]ts role is more modest: it keeps the parties to their contract." II9

Yet, it is interesting to note that these were long-established principles, as the 1940 case of McDonald $v$. Burns ${ }^{\mathrm{I} 20}$ made only too clear. There, Lord Justice Clerk Aitchison explained the two sets of circumstances justifying judicial intervention. First, where the religious association has acted clearly and demonstrably beyond its own contractual constitution ${ }^{\mathrm{I} 2 \mathrm{I}}$ that is "in a manner calculated to affect the civil rights and patrimonial interests of any of its members." ${ }^{22}$ Second, whereas the religious association has acted within its own constitution, "the procedure of its judicial or quasi-judicial tribunals has been marked by gross irregularity." ${ }^{23} 3$ The only caveat is that the irregularity "must go to the honesty and integrity of the proceedings complained of." 224 This suggests that even where an act is intra vires, a gross irregularity of procedure will make the action judicially reviewable. Therefore, whether a religious body in relation to its powers is acting ultra vires or intra vires, a secular court may in appropriate cases intervene to rectify gross irregularities.

Such is the pace of change in the secular courts regarding religious disputes arising before them that theology, in itself, no longer trumps jurisdiction. In the recent case of Hodkin, the issues of theology were in fact avoided by the courts so that individual rights and interests could be enforced in the public law of the land. Here the UK Supreme Court addressed the question of whether the Church of Scientology is a "religion" for the purposes of the Places of Worship and Registration Act I 885 (hereafter the Act of I 885 ), the latter being the public law of the land, and in the context of which private interests had to be determined. Lord Toulson, rather than engage with the theology of Scientology, just described it as a religion for the purposes of the Act of $188_{5}$, on the basis that religion is a term wide enough to embrace any spiritual or nonsecular belief system (not confined to the worship of a supreme deity) that is held by a group of adherents and that claims to explain mankind's place in the universe and its relationship with the infinite. ${ }^{\mathrm{I} 25}$ This is because it would be inappropriate for the courts (or Registrar General) to determine the difficult theological question of whether a belief in Scientology would constitute a religion. ${ }^{226}$ Such a sophisticated and finespun response from the Supreme Court is unsurprising given the increasing subtleties of religious cases now coming up before the courts. ${ }^{\mathrm{I} 27}$ These in turn affect the evaluation of what can properly be regarded as justiciable before the courts. It is for this reason that the courts sometimes refrain from a consideration of the theological questions before them. This is just what happened in Hodkin. Russell Sandberg in "Defining the Divine" has suggested that this is only a description, not

I 19 Shergill \& Ors v. Khaira \& Ors [20I4] UKSC 33 , para. 48.

I 20 [ 1940 O ScotCS CSIH 3.

I2I This is the document that sets out the essential tenets of its religious doctrine.

I22 McDonald v Burns [I940] ScotCS CSIH 3 (March 29, I940), http://www.bailii.org/scot/cases/ScotCS/I940/ I940_SC_376.html.

I 23 Ibid.

I24 Ibid.

I25 Shergill \& Ors v Khaira \& Ors [20I7] EWHC $88_{3}$ (Ch) (March 3, 20I7), http://www.bailii.org/ew/cases/EWHC/ $\mathrm{Ch} / 2017 / 883 \cdot \mathrm{html}$.

I 26 For an early commentary, see Frank Cranmer, "Disputed Trusteeship: Shergill v Khaira Yet Again," Law and Religion UK (blog), April 2I, 20I7, http://www.lawandreligionuk.com/20I7/04/2I/disputed-trusteeship-shergill-v-khaira-yet-again/.

I27 Ibid., para. 49 . 
a definitive formula, ${ }^{\mathrm{I} 28}$ but the attractiveness of such a proposition from the Supreme Court is that by avoiding a detailed consideration of questions of theology, it avoids having to decide what is justiciable and what is not, and it thus helpfully includes a number of established faiths, such as Buddhism and Jainism into the penumbra of "religion" from which they had previously been excluded. ${ }^{\mathrm{I} 29}$

\section{THE OUTCOME IN SHERGILL: THE COURTS VINDICATED}

What was the eventual outcome in Shergill itself? And is there any evidence that the courts can, when put to the test, resolve arcane issues of doctrine and practice with the required ability and dexterity in modern pluralistic society, especially when it comes to religious traditions that are not their own? In March 2017, judgment was given by the High Court in Shergill on the substantive issues ${ }^{\mathrm{I}}{ }^{\circ}$ when it set out to apply the strictures handed down to it by the Supreme Court two years earlier. ${ }^{\mathrm{I}{ }^{\mathrm{I}}}$ The results are truly astonishing, as decision making by the secular courts goes in matters of religion. The judgment by Judge Purle QC is not only a model of judicial acumen, clarity, and fair-mindedness of the secular courts but also a stark illustration of how those from a different faith, with the advantage of being outsiders looking in on a faith of others, often can understand the essential values and nuances of another religion far better than those who are born within the same faith. Judge Purle QC tackled the issue of the appropriateness of the present incumbent of the Holy Order of the Nirmala Kutia assuming and continuing in office by observing at the outset that, "the allegation [was] that the Third Holy Saint, though a follower of Sikh mainstream discipline at the time of his appointment, had so departed from the mainstream since that he could no longer be regarded as qualified at all" ${ }^{{ }^{3} 2}$; that the court would look at the evidence; and that he was "bound to say that if the evidence established that that truly was the position in relation to the Third Holy Saint, or, to take an extreme example, that he had ceased to be a Sikh at all and instead had become a Hindu, then I would be very reluctant to grant any relief. ${ }^{133}$ Judge Purle QC considered how, "the Nirmala tradition under which there are Holy Saints, upon whom especial reverence is cast, is or may be abhorrent to some Sikhs because it suggests that the Holy Saint is the equivalent of a living Guru, which is sacrilegious." ${ }^{3} 4$ The judge even recognized its potential significance in the context of the Sikh religion, noting how, "[m]any would say, amongst conservative Sikhs, that the Nirmalas generally, including this particular institution, were of doubtful legitimacy because the Guru element, to which a Holy Saint may be said to be akin," but that "[w]hat needs to be shown is that the brand of Sikhism that has been practised under the Third Holy Saint has so changed since the days of the First and Second Holy Saints that it can be said to be something radically different, so as to give rise schismatically to a separate brand of religion that may not even be Sikhism.” ${ }^{2} 35$

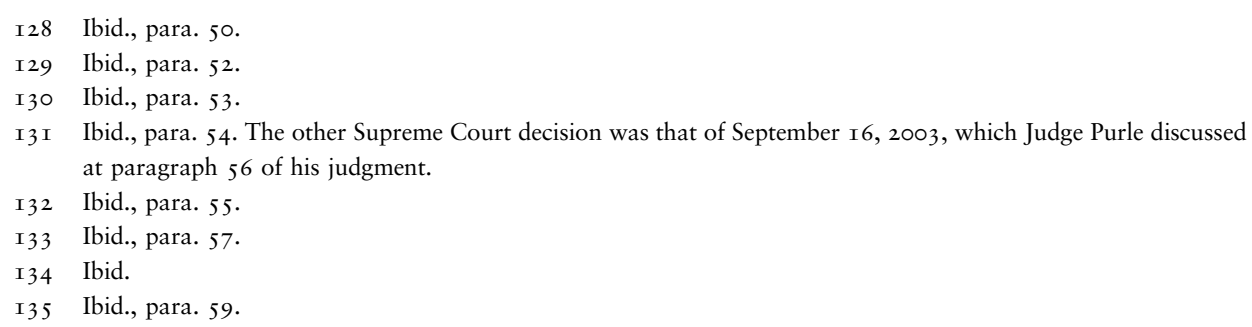


In an exercise of the judicial function quite reminiscent of that by the courts during the nineteenth-century Scottish religious schisms in the Presbyterian Church, Judge Purle QC even looked at two Indian Supreme Court decisions that went against the Nirmalas, "the first being in 1967, concerning Nirmala Sadhus whose activities were challenged by Sikhs. They were held, in essence, not to be Sikhs at all." ${ }_{36} 6$ The judge explained that he had

read all that because it demonstrates that what one needs to focus upon is not simply the structure of an organisation, or what it calls itself, but the tenets and practises which its adherents follow. It has not been shown in this case, for example, that the adherents or followers at Nirmal Kutia Johal worship anything other than the Guru Granth Sahib, and nor has it been shown that they-which is the other side of the coin-worship graves, tombs or are guilty of any other form of idolatry. Nor is it shown that they have departed from the Sikh customs of, for example, baptism. Indeed, the evidence is that the Third Holy Saint holds himself out as being a baptised Sikh and has himself baptised thousands of Sikhs. ${ }^{\mathrm{I} 7}$

The judge went onto explain how the expert witness, "went to Nirmal Kutia Johal and attended (anonymously) what he thought was a Gurdwara" and that, "if upon entry into the building he had observed idolatry or other Hindu practises, he would surely have said so, but he was quite clear that he was at a Sikh institution which he thought was a Gurdwara." ${ }^{3} 8$ Accordingly, as Judge Purle QC put it, "If I ask myself what religion today is being practiced at Nirmal Kutia Johal then the answer is: the Sikh religion as laid down in the constitution and trust deeds, in substantially the same way in it which has always been carried on at Nirmal Kutia Johal." ${ }_{339}$ What is ultimately so discerning about this judgment of the High Court, however, is the way in which it even differs from leading judgments in India, which implied that "the Third Holy Saint had moved over to what the Supreme Court held was Hinduism in the two decisions." I40 The basis of this view was that under the present Third Holy Saint, the Nirmal Kutia Johal was "affiliated if not subservient" ${ }^{\text {I4I }}$ to the Kankhal, "which the Supreme Court has held, in effect, to be a Hindu institution." ${ }^{142}$ But the evidence was that there were also no less than " 33 allied Nirmala institutions" to the Kankhal in India, and, "there is no evidence that the Kankhal organisation in any way interferes in the running of the Johal organisation or lays down the worshipping practises or rites which have to be followed and which are said to be contrary to Sikhism." ${ }^{4} 43$

In striking out his own clear path, on the evidence that he had heard himself in the High Court, Judge Purle QC even distinguished the decisions of the Indian courts from his own. He ruled that what the Indian courts had decided "must be taken to be the law for the purposes of the legislation that the Indian court was considering," but that "it does not touch upon the question which I have to decide, which is whether or not the Third Holy Saint has so departed from the principles of

\footnotetext{
I36 Ibid.

I37 Ibid., para. 68.

${ } 38$ Ibid.

I39 Ibid., para. 69.

I40 Shergill \& Ors v. Khaira \& Ors [20I4] UKSC 33 , para. 45.

I4 I Ibid., para. 46.

I 42 Cranmer, "Is Religious Doctrine Justiciable? Up to a Point, Yes: Shergill v Khaira," Law and Religion UK (blog), June I I, 20I4, http://www.lawandreligionuk.com/20I4/06/I I/is-religious-doctrine-justiciable-up-to-a-point-yeskhaira-v-shergill/.

I43 Neil Addison, “Shergill v. Khaira - When Can Religious Doctrine Be Justiciable?,” Religion Law (blog), June I2, 20I4, http://religionlaw.blogspot.com/2014/o6/shergil-v-khaira-when-can-religious.html.
} 
Sikhism as to disqualify him from discretionary relief.” ${ }^{4} 4$ On this question, the High Court was clear: he had not.

To sum up: If the Supreme Court in Shergill made religion justiciable again as a matter of judicial doctrine, the High Court in Shergill made it clear how practically important it is to have the regular courts of the realm determine such issues definitively and decisively. In the Shergill case, the dispute had been ongoing for more than a decade, with little end in sight. Though it may seem bold to suggest it, the judgments of the Supreme Court and the High Court in the United Kingdom may well be seen as a beacon of light in other countries-and not least in India, where the courts may wish to revisit their decisions in such matters.

\section{CONCLUSION}

"Justiciability" remains important because its boundaries are often blurry and in a state of flux. Not everything is justiciable. Courts do not adjudicate on whether or not Jesus rose from the dead. Nor do they adjudicate on whether or not acceptance of the Four Noble Truths relieves one from suffering in this life. But they do adjudicate on whether or not a particular religious group that lays claim to a property adheres to the doctrines of the religion for which the creators of the trust made the endowment. In Shergill the Supreme Court robustly defended the idea that when a claimant asks the court to enforce private rights and obligations created by public law but that depend on religious issues, the judge may have to determine that such questions can be objectively assessed. ${ }^{\mathrm{I}} 45$ Private rights and obligations can be enforced by the courts. Jurisdiction exists to determine disputes regarding ownership, possession, and control of property held in trusts for religious purposes. Unincorporated religious communities, such as Sikh temples, mosques, and other religious institutions are to be treated as voluntary associations, ${ }^{146}$ so that the agreed constitution of a voluntary religious association is a civil contract, in just the same way as the contract of association of a secular body.

As Frank Cranmer has explained, the Shergill decision does more than "shift ... the boundary slightly and enlarge the circumstances in which the court will feel able to intervene," ${ }_{47}$ or merely "push the door of non-justiciability open by a crack." ${ }^{4} 48$ The decision is important because it "potentially heralds a return to what has been described as the 'nineteenth century' concept of nonjusticiability." ${ }^{4} 49$ Here judges went to great lengths to place distance between themselves and

I44 Smith, "The Problem of the Non-Justiciability of Religious Defamations," 255-56.

I45 Rivers, The Law of Organized Religions, 73.

I46 The States of Guernsey \& Anor v. Secretary of State for Environment, Food and Rural Affairs \& Anor [20I6] EWHC I 847 , para. 74 (Jay J). Mr. Justice Jay was referring to paragraphs $42-43$ of Shergill, but as he himself pointed out, "these labels were not deployed [in Shergill]" but are a useful way to summarize what the Supreme Court had in mind.

I47 R (on the application of Hodkin and another) v. Registrar General of Births, Deaths and Marriages [20I3] UKSC 77 , para. 57.

I48 Ibid., para. 54

I49 Nevertheless, it has been observed that

the legal system does have experience in attempting to define a religion and in establishing principles by which to recognise religions. This shows that no single or universal definition is possible. One context in which the concept is explored is in cases involving charitable trusts set up for the advancement of religion. In re: South Palace Ethical Society, Mr. Justice Dillon held that a society for the study and dissemination of ethical principles that did not involve faith in a deity could not constitute religion. He said, "In a free country 
matters touching upon religion so as to create an aura of neutrality around them by "pointing out that it was no role of a court of law to act as a religious insider delivering "correct" answers to the underlying substantive theological or ecclesiological dispute between the parties." In this manner the courts would "regularly proceed to point out that questions of doctrine and discipline might well be relevant as questions of fact to determine the outcome of the case," ${ }_{50}$ provided that they could find the evidence do so. What this means is that a judicial tribunal, as the Supreme Court in Shergill makes clear, will only adjudicate the decision of an association's governing body if there is a question of infringement of a civil right or interest and the question is determinable as a matter of evidence. Its impact has been widely felt so that as Mr. Justice Jay in the High Court explained how so long as there is a "maintenance of the conceptual division between 'judicial forbearance' being "based on a lack of institutional competence in the judiciary based on the subject-matter," which in itself would have a "rare application" and a "lack of legal relevance" being claims or defenses "based neither on private legal rights or obligations, nor on reviewable matters of public law," adjudication on religious matters is now open to the courts. ${ }^{15}$ I

So, the intriguing question is whether there are now, subject to these provisos, any limits left at all to the justiciability of religious questions. Peter Smith has observed how "most of the occasions on which the courts have decided religious truths have concerned Christian theology," but that is hardly surprising given "the composition of the judiciary" in the United Kingdom. The eleven judges are all white, and with the exception of one notable woman amongst them, all male, with Christian and Jewish heritage. Accordingly, as he points out, "it is reasonable to infer that most judges will be much more familiar with Christian doctrine and practice than with Hinduism or Islam," ${ }^{52}$ both of which are relative newcomers as faith systems in their midst. If this is right, would it not then be altogether both more prudent and more practical for the judiciary to eschew a consideration of matters that require detailed knowledge of the working and internal practices of such minority faith religions? Put another way, was the Court of Appeal judgment of Mummery LJ right after all in determining that the correct judicial stance for a court is to distance itself from deciding a dispute in a religion such as Sikhism whose adherents number around half a million people in a national population of 64 million in the United Kingdom, such that they would ordinarily know little about them as a religious community? Not necessarily. Whereas there are certainly weighty arguments in favor of greater judicial diversity in the United Kingdom's apex court, this

\footnotetext{
... it is natural that the court should desire not to discriminate between beliefs deeply and sincerely held, whether they are beliefs in God or in the excellence of man or in ethical principles or in Platonism or some other scheme of philosophy. But I do not see that that warrants extending the meaning of the word "religion" so as to embrace all other beliefs and philosophies. Religion, as I see it, is concerned with man's relations with God, and ethics are concerned with man's relations with man. The two are not the same, and are not made the same by sincere inquiry into the question, what is God. If reason leads people not to accept Christianity or any known religion, but they do believe in the excellence of qualities such as truth, beauty and love, or believe in the Platonic concept of the ideal, their beliefs may be to them the equivalent of a religion, but viewed objectively they are not religion .... It seems to me that two of the essential attributes of religion are faith and worship; faith in God and worship of that God.
}

Re South Place Ethical Society Barralet and Others v. Attorney General and Others [1980] I WLR I 565, at I 57 I (quoting Bob Hepple QC and Tufyal Choudhury, “Tackling Religious Discrimination: Practical Implications for Policy-Makers and Legislators," Home Office Research Study 22I (London: Home Office Research, Development and Statistics Directorate, 200I), 27-28, http://www.religionlaw.co.uk/reportae.pdf).

I 50 Russell Sandberg, "Defining the Divine," Ecclesiastical Law Journal 6, no. 2 (2014): 198-204.

I 5 I See R v. Registrar General ex parte Segerdal and another [I970] 3 All ER 886.

I 52 Smith, "The Problem of the Non-Justiciability of Religious Defamations," 257. 
is no reason for disentitling or disqualifying a secular court from resolving issues of fact. This article has suggested that there are likely to be few if any limits left to how far the court can go in resolving a religious dispute on grounds of nonjusticiability where private rights and interests created by public law are at stake. In the changed circumstances of modern, multicultural, and pluralistic society this development is to be much welcomed in contemporary democratic society. What will matter nowadays are not the arid distinctions between belief, doctrine, and church practice but the individual interests at stake.

\section{ACKNOWLEDGMENTS}

The author would like to record his thanks to Silas W. Allard and Julian Rivers for their insightful comments on an earlier draft of this article, and to his research assistant, Olivia Pattison. Needless to say, all remaining errors are his own. 